\title{
Pendidikan Kesehatan tentang Peran Ibu dalam Deteksi Dini Stunting di Wilayah Kerja Puskesmas Simpang Kawat Kota Jambi
}

\author{
Gustina \\ Program Studi D III Kebidanan, STIKes Baiturrahim Jambi \\ Email: gtina1870@gmail.com
}

Submitted : 01/01/2021

Accepted: 03/01/2021

Published: 11/01/2021

\begin{abstract}
The problem of stunting (stunting) is one of the nutritional problems faced in the world, especially in poor and developing countries). Stunting is a problem because it is associated with an increased risk of illness and death, suboptimal brain development, resulting in delayed motor development and stunted mental growth. These nutritional problems can be overcome when they understand the problem and know how to solve it according to their respective conditions (Ramayulis et al, 2018).Target and Outcome: Increased role of mothers with under-five children in early detection of stunting, which aims to reduce the incidence of stunting in under-five.Method of implementation: Administrative preparation, socialization, implementation of health education and evaluation. Activities were carried out from September 2019 to January 2020 by providing education to mothers about the role of mothers in early detection of stunting. Evaluation is done by looking at the results of the pre-test and post-test scores for the mother. Located at Posyandu Lebak Bandung, the Work Area of the Simpang Kawat Puskesmas, Jambi City.Results: After preparation, socialization, implementation and evaluation of the results of the pre-test and post-test scores before health education was carried out on early detection of stunting, out of 15 respondents the role of mother was Poor 9 (60\%), Enough 6 (40\%), and Good 0 (0\%). After health education was carried out about early detection of stunting, from 15 respondents the role of mother was Poor 0 (0\%), Enough 4 (26.6\%), and Good 11 (73.3\%).Conclusion: There was increased knowledge of mothers before and after health education on early detection of stunting. Suggestion: For mothers to always increase knowledge about motherhood through electronic media.
\end{abstract}

Keywords: detection, posyandu, stunting, toddler mothers

Abstrak

Masalah anak pendek (stunting) merupakan salah satu permasalahan gizi yang dihadapi di dunia, khususnya di negara-negara miskin dan berkembang). Stunting menjadi permasalahan karena berhubungan dengan meningkatnya risiko terjadinya kesakitan dan kematian, perkembangan otak suboptimal sehingga perkembangan motorik terlambat dan terhambatnya pertumbuhan mental. Permasalahan gizi ini bisa diatasi ketika mereka memahami masalahnya dan mengetahui cara mengatasinya sesuai dengan kondisi masing-masing (Ramayulis dkk, 2018). Target dan luaran: Meningkatnya peran ibu yang mempunyai anak Balita dalam deteksi dini stunting, yang bertujuan untuk menurunkan kejadian stunting pada Balita.Metode pelaksanaan: Persiapan administrasi, sosialisasi, pelaksanaan pendidikan kesehatan dan evaluasi. Kegiatan dilaksanakan pada bulan September 2019 sampai Januari tahun 2020 dengan cara memberikan pendidikan kepada ibu tentang peran ibu dalam deteksi dini stunting. Evaluasi dilakukan dengan melihat hasil nilai pre test dan post test pada ibu. Bertempat di posyandu Lebak Bandung Wilayah Kerja Puskesmas Simpang Kawat Kota Jambi. Hasil: Setelah dilakukan persiapan, sosialisasi, pelaksanaan dan evaluasi hasil nilai pre test dan post test sebelum dilakukan pendidikan kesehatan tentang deteksi dini stunting, dari 15 responden peran ibu Kurang baik 9 (60\%), Cukup 6 (40\%), dan Baik $0(0 \%)$. Setelah dilakukan pendidikan kesehatan tentang deteksi dini stunting adalah dari 15 responden peran ibu Kurang baik 0 (0\%), Cukup 4 (26.6\%), dan Baik 11 (73.3\%). Kesimpulan: Terjadi peningkatan pengetahuan ibu sebelum dan setelah dilakukan pendidikan kesehatan tentang deteksi dini stunting.

Kata Kunci: Ibu Balita, deteksi, stunting, Posyandu 


\section{PENDAHULUAN}

Masalah anak pendek (stunting) merupakan salah satu permasalahan gizi yang dihadapi di dunia, khususnya di negara-negara miskin dan berkembang). Stunting menjadi permasalahan karena berhubungan dengan meningkatnya risiko terjadinya kesakitan dan kematian, perkembangan otak suboptimal sehingga perkembangan motorik terlambat dan terhambatnya pertumbuhan mental. Beberapa studi menunjukkan risiko yang diakibatkan stunting yaitu penurunan prestasi akademik, meningkatkan risiko obesitas lebih rentan terhadap penyakit tidak menular dan peningkatan risiko penyakit degenerative (Unicef Indonesia, 2016).

Pencegahan stunting melalui intervensi gizi spesifik yang ditujukan dalam 1000 hari pertama kehidupan. Intervensi gizi spesifik untuk mengatasi permasalahan gizi pada hamil, ibu menyusui 0-6 bulan, ibu menyusui 6-23 bulan, anak usia 0-6 bulan, dan anak usia 7-23 bulan. Permasalahan gizi ini bisa diatasi ketika mereka memahami masalahnya dan mengetahui cara mengatasinya sesuai dengan kondisi masing-masing (Ramayulis dkk, 2018).

Faktor - faktor yang dapat menyebabkan kekerdilan (Stunting) menurut Kemenkes RI (2017) yaitu sebagai berikut diantaranya adalah faktor gizi buruk yang dialami ibu hamil maupun anak balita, kurangnya pengetahuan ibu mengenai kesehatan dan gizi sebelum dan pada masa kehamilan, serta setelah ibu melahirkan, masih terbatasnya layanan kesehatan termasuk layanan ANC (Antenatal Care) pelayanan kesehatan ibu selama kehamilan, post natal care dan pembelajaran dini yang berkualitas, masih kurangnya akses kepada makan bergizi dan kurangnya akses air bersih dan sanitasi.

Upaya intervensi yang dilakukan dalam Kemenkes RI ada 4 program yaitu (1) Ibu hamil perlu mendapat makanan yang baik, sehingga apabila ibu hamil tidak mengalami Kurang Energi Kronis (KEK). Setiap ibu hamil perlu mendapat tablet tambah darah, minimal 90 tablet selama kehamilan. (2) pada saat bayi lahir Persalinan ditolong oleh bidan atau dokter terlatih dan begitu bayi lahir melakukan Inisiasi Menyusu Dini (IMD). Bayi sampai dengan usia 6 bulan diberi Air Susu Ibu (ASI) saja (ASI Eksklusif). (3) bayi berusia 6 bulan sampai dengan 2 tahun Mulai usia 6 bulan, selain ASI bayi diberi Makanan Pendamping ASI (MP-ASI). Pemberian ASI terus dilakukan sampai bayi berumur 2 tahun atau lebih. Bayi dan anak memperoleh kapsul vitamin A, imunisasi dasar lengkap. (4) memantau pertumbuhan Balita di posyandu merupakan upaya yang sangat strategis untuk mendeteksi dini terjadinya gangguan pertumbuhan (Kemenkes RI, 2018).

Pencegahan stunting melalui intervensi gizi spesifik yang ditujukan dalam 1000 hari pertama kehidupan. Intervensi gizi spesifik untuk mengatasi permasalahan gizi pada hamil, ibu menyusui 0-6 bulan, ibu menyusui 6-23 bulan, anak usia 0-6 bulan, dan anak usia 723 bulan. Permasalahan gizi ini bisa diatasi ketika mereka memahami masalahnya dan mengetahui cara mengatasinya sesuai dengan kondisi masing-masing (Ramayulis dkk, 2018).

Puskesmas sudah mempunyai posyandu dan telah melaksanakan kegiatan terjadwal, tetapi belum fokus membahas pada deteksi dini stunting.Untuk meningkatkan peran ibu dalam membantu deteksi dini sebagai upaya penurunan kejadian stunting pada Balita di perlukan pendidikan kesehatan tentang peran ibu dalam deteksi dini stunting diwilayah kerja Puskesmas Simpang Kawat.

\section{TARGET DAN LUARAN}

Meningkatnya peran ibu yang mempunyai anak Balita dalam deteksi dini stunting, yang bertujuan untuk menurunkan kejadian stunting pada Balita.

\section{METODE PELAKSANAAN}

Kegiatan dilaksanakan selama satu semester ganjil dimulai Bulan September tahun 
2019 sampai dengan Januari 2020 di posyandu Lebak Bandung di Wilayah Kerja Puskesmas Simpang Kawat Kota Jambi.

Pelaksanaan diawali dengan persiapan administrasi, sosialisasi: tujuan, manfaat, kemudian dilaksanakan pendidikan kesehatan pada ibu yang mempunyai Balita dan evaluasi hasil pendidikan kesehatan dengan melihat nilai pre tes dan post test.

\section{HASIL DAN PEMBAHASAN}

Setelah mengikuti serangkaian kegiatan sesuai dengan rencana pelaksanaan maka hasil sebagai berikut:

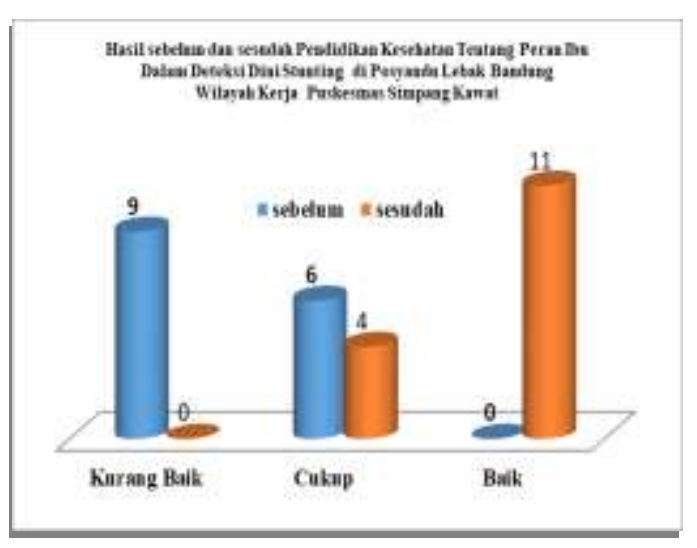

Diagram 4.1. Hasil sebelum dan sesudah Pendidikan Kesehatan Tentang Peran ibu dalam Deteksi Dini Stunting di Posyandu Lebak Bandung Puskesmas Simpang Kawat Tahun 2019

Dari diagram 4.1 diatas didapatkan hasil, sebelum dilakukan pendidikan kesehatan tentang deteksi dini stunting, dari 15 responden peran ibu Kurang baik 9 (60\%), Cukup 6 (40\%), dan Baik $0(0 \%)$. Setelah dilakukan pendidikan kesehatan tentang deteksi dini stunting adalah dari 15 responden peran ibu Kurang baik $0(0 \%)$, Cukup 4 (26.6\%), dan Baik 11 (73.3\%).

Pencegahan stunting melalui intervensi gizi spesifik yang ditujukan dalam 1000 hari pertama kehidupan. Intervensi gizi spesifik untuk mengatasi permasalahan gizi pada hamil, ibu menyusui 0-6 bulan, ibu menyusui 6-23 bulan, anak usia 0-6 bulan, dan anak usia 7-23 bulan. Permasalahan gizi ini bisa diatasi ketika mereka memahami masalahnya dan mengetahui cara mengatasinya sesuai dengan kondisi masing-masing (Ramayulis dkk, 2018).

Upaya pencepatan penurunan Stunting menurut Germas (2019) adalah dengan intervensi gizi spesifik melalui PMT untuk mengatasi KEK pada ibu hamil, TTD untuk ibu hamil, konsumsi garam beriodium, ASI Ekslusif, pemberian ASI sampai usia 2 tahun didampingi dengan MP ASI adekuat, imunisasi, suplemen zink, fortifkasi zat besi ke dalam makanan, obat cacing, VitaminA, tata laksana gizi buruk, penanggulangan malaria, pencegahan dan pengobatan diare dan cuci tangan dengan benar.

Konsep dan upaya pencepatan penurunan Stunting pada Balita apabila sedini mungkin ditemukan oleh ibu, tentu saja akan memudahkan dalam melakukan intervensi untuk mengatasi permasalahan gizi pada awal ibu hamil dan Balita. Hasil dari pengabdian kepada masyarakat didapatkan hasil dari 15 responden peran ibu sebelum dilakukan pendidikan kesehatan Kurang baik 9 (60\%) dan Baik 0 $(0 \%)$ dan setelah dilakukan pendidikan kesehatan Kurang Baik 0 (0\%) dan Baik 11 (73.3\%). Hasil dari pendidikan kesehatan terlihat bahwa terjadi perubahan perilaku peran ibu yaitu dalam deteksi dini stunting terlihat dari hasil pengetahuan Kurang Baik menjadi Baik. Setelah dilakukan kegiatan pendidikan kesehatan sesuai dengan teori Benyamin Bloom 1908 dalam Notoatmodjo (2016).

Benyamin Bloom 1908 dalam Notoatmodjo (2016). Pengetahuan adalah bentuk perilaku berupa respon atau reaksi terhadap stimulus atau rangsangan dari luar organisme (orang). Namun dalam memberikan respon sangat tergantung pada karakteristik atau faktor faktor lain dari orang yang bersangkutan. Hal ini berarti meskipun stimulusnya sama bagi beberapa orang, namun respon tiap - tiap orang berbeda.

Pengetahuan merupakan hasil dari tahu dan ini terjadi setelah orang melakukan penginderaan terhadap suatu objek tertentu. 
Penginderaan terjadi melalui pancaindera manusia yakni indera penglihatan, pendengaran, penciuman, rasa dan raba. Sebagian besar pengetahuan manusia diperoleh melalui mata dan telinga.

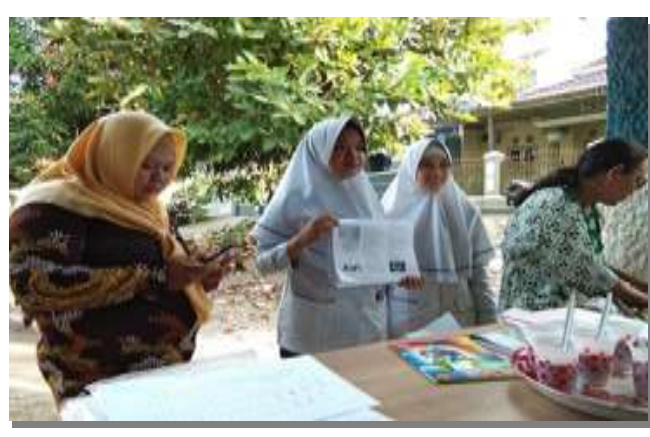

Gambar 2. Pendidikan Kesehatan

\section{KESIMPULAN DAN SARAN}

\section{Kesimpulan}

Hasil yang dapat disimpulkan bahwa terjadi peningkatan pengetahuan ibu sebelum dan setelah dilakukan pendidikan kesehatan tentang deteksi dini stunting sebagai berikut:

1) Dari 15 responden peran ibu sebelum dilakukan pendidikan kesehatan Kurang baik $9(60 \%)$ dan Baik $0(0 \%)$

2) Dari 15 responden pengetahuan setelah dilakukan pendidikan kesehatan Kurang Baik 0 (0\%) dan Baik 11 (73.3\%)

Dapat disimpulkan bahwa terjadi peningkatan ilmu pengetahuan tentang peran ibu sebelum dan sesudah dilakukan pendidikan kesehatan tentang deteksi dini stunting pada pada ibu yang mempunyai anak Balita.

\section{Saran}

Dari kesimpulan dapat disarankan pada ibu untuk selalu menambah ilmu pengetahuan tentang peran ibu melalui media elektronik. Tetap membawa Balita ke posyandu untuk melihat tumbuh kembang Balita dan dapat dideteksi secara dini. Jika ditemukan secara dini maka diharapkan kejadian stunting dapat dilakukan intervensi secara cepat dan tepat oleh tenaga kesehatan.

\section{UCAPAN TERIMAKASIH}

1. Kepala Puskesmas Simpang Kawat dan Penanggungjawab Pustu Lebak Bandung yang telah memberikan kemudahan dalam pelaksaan pendidikan keshatan di posyandu Lebak Bandung.

2. Bapak Ketua dan jajaran STIKes Baiturrahim yang memberikan dukungan moril dan materil sehingga terlaksananya kegiatan pengabdian kepada masyarakat ini.

\section{DAFTAR PUSTAKA}

Arikunto, Suharsimi. 2010. Prosedur Penelitian SuatuPendekatan Praktik. Jakarta: RinekaCipta.

Balitbangkes. 2015. Pendek (Stunting) di Indonesia Masalah dan Solusinya. Jakarta: Lembaga Penerbit Balitbangkes.

Dinas Kesehatan Kota Jambi. (2019) .Jumlah Kunjungan Ibu Hamil di Kota Jambi Tahun 2018. Jambi

Dinas Kesehatan Provinsi Jambi (2019). Jumlah Kejadian Stunting di Provinsi Jambi Tahun 2018. Jambi

Geramas. 2019. Kebijakan dan Strategi Penanggulangan Stunting di Indonesia. Jakarta.

https://www.who.int/news/item/19-112015-stunting-in-a-nutshell.

https://www.unicef.org/burundi/stories/effo rts-overcome-stunting.

Kalla .2017.Buku Saku dalam penangan stunting.Jakarta :Rineka Cipta

Kemenkes RI. 2018. Pusat dan Informasi (Stunting). Jakarta

Manuaba .2008. Ilmu dan Kebidanan Penyakit Kandungandan KB. Jakarta : EGC

Notoadmojo, Soekidjo. 2016. Promosi Kesehatan Teori dan Aplikasi. Jakarta: Rineka Cipta.

Proverawati. (2017). Ilmu Gizi Kebidanan. Yogyakarta : EGC 
Jurnal Abdimas Kesehatan (JAK) Vol 3, No 1, Januari 2021

Doi : $10.36565 /$ jak.v3i1.149

p-ISSN: 2655-9266

e-ISSN: 2655-9218

Ramayulis, dkk. 2018. Stop Stunting

Dengan Konseling Gizi. Jakarta: Penebar Swadaya Grup.

Riskesdas. 2018. Riset Kesehatan Dasar. Jakarta.

Walyani.E. 2015. Asuhan Kebidanan Pada

Kehamilan .Yogyakarta : Pustaka Baru Press.

WHO Stunting in a nutshell World Health

Organization, 2015. 